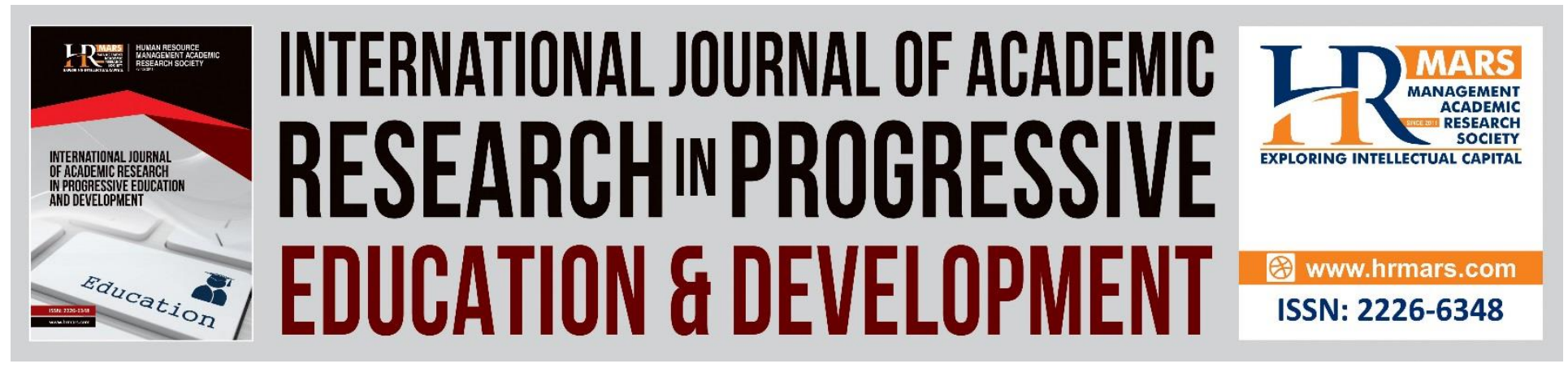

\title{
Role of Parents in Remedial Pupil's Academic Achievement
}

Kannamah Mottan, Dhurgavathi Shanmugam

To Link this Article: http://dx.doi.org/10.6007/IJARPED/v7-i4/4845

DOI: $10.6007 /$ IJARPED/v7-i4/4845

Received: 11 Oct 2018, Revised: 28 Oct 2018, Accepted: 13 Nov 2018

Published Online: 17 Nov 2018

In-Text Citation: (Mottan \& Shanmugam, 2018)

To Cite this Article: Mottan, K., \& Shanmugam, D. (2018). Role of Parents in Remedial Pupil's Academic Achievement. International Journal of Academic Research in Progressive Education and Development, 7(4), 166-178.

Copyright: (C) 2018 The Author(s)

Published by Human Resource Management Academic Research Society (www.hrmars.com)

This article is published under the Creative Commons Attribution (CC BY 4.0) license. Anyone may reproduce, distribute, translate and create derivative works of this article (for both commercial and non-commercial purposes), subject to full attribution to the original publication and authors. The full terms of this license may be seen

at: http://creativecommons.org/licences/by/4.0/legalcode

Vol. 7, No. 4, 2018, Pg. 166 - 178

http://hrmars.com/index.php/pages/detail/IJARPED

JOURNAL HOMEPAGE

Full Terms \& Conditions of access and use can be found at http://hrmars.com/index.php/pages/detail/publication-ethics 


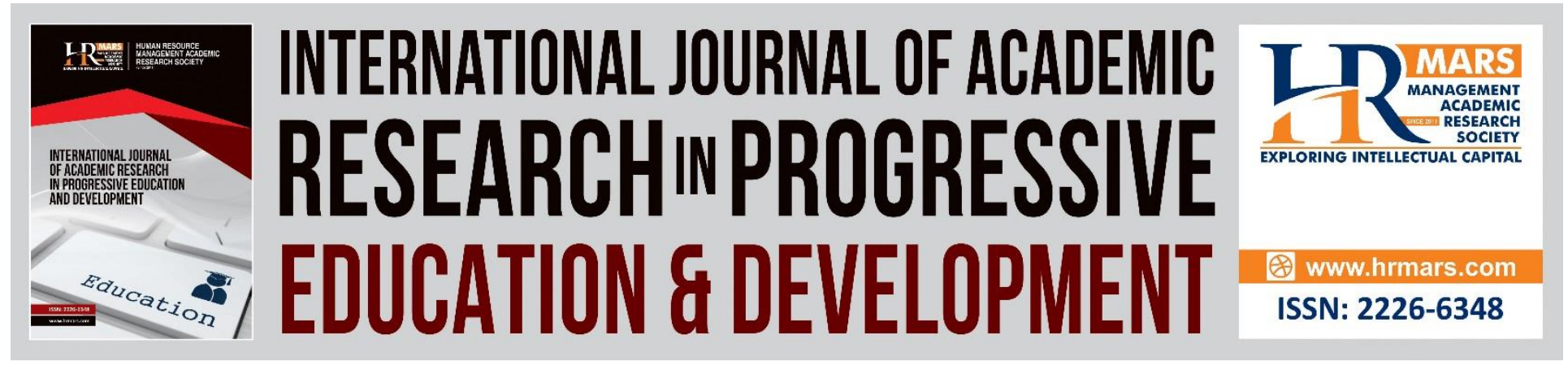

\title{
Role of Parents in Remedial Pupil's Academic Achievement
}

\author{
Kannamah Mottan, Dhurgavathi Shanmugam \\ Faculty of Human Development, Universiti Pendidikan Sultan Idris, Malaysia
}

\begin{abstract}
The objectives of the research were to identify parents understanding on remedial class or in interchangeably, special remedial class, the relationship between parent's involvement and pupil's academic achievement, relationship between parent's communication and the school and the relationship between parent's background and pupil's academic achievement. A descriptive survey method using a validated questionnaire (cronbach alpha, 0.944) was used to gather data from 35 respondents from two Tamil schools in Penang, Malaysia. The dimensions studied were parents' knowledge about remedial programme, provision of learning atmosphere, interaction with children in the house, support towards their children's involvement in school and lastly parent's background. The analysis of the data showed the interaction with the children had the highest mean value, mean=3.69 (S.D. $=0.74$ ) and the involvement in school with mean=2.93 (S.D. $=0.60$ ) was the lowest. Correlation variance analysis indicated a strong to moderate significant positive relationship between provision of learning atmosphere, interaction with children, support towards their children and involvement in school with increasing children's performance in academic achievement. There was no significant relationship between parent's education level, working hours and family income with children's performance in school academic. Implication from this research is that irregardless of parents' background and economic status they take initiatives to help their children with remedial problems at home and are willing to work with schools to their capacity. Teachers have to be studied too to look deeper into the issue. Keywords: Remedial Class, Special Remedial Class, Tamil School, Parent's Involvement, Academic Achievement
\end{abstract}

\section{Introduction and Background}

Role of parents in children's academic achievement is of utmost importance. A child's first teacher is his parents. Parents can either break or create excellence in their children. This is notwithstanding race and religion. Hamer (2012) says that the parents first three years with the child gives more impact than social encounters. This is because it prepares them to mingle among friends and to study. This role has to be sustained in order for the children to achieve holistic excellence. Academic achievement of Tamil school pupils in Malaysia had always been a question 
Vol. 7, No. 4, 2018, E-ISSN: 2226-6348 ๑ 2018 HRMARS

mark in the 60s, 70s and 80s. But due to a re-engineering task undertaken in the 90s, Tamil schools have undergone metamorphosis. Rarely do we see news on remedial or special remedial classes and to what extent it is effective in Tamil schools, or do we need special needs classes at all. (Kannamah, 2012). In addition, very often than not we read the achievements of Tamil school pupils in the newspapers and the social media. Yet there are many untold stories of underachievers. News on this is just swept under the carpet. These underachievers are not neglected in schools. Teachers and administrators take great effort to help these children. Yet the nurturing factor from the house seems to be a pulling down factor. This pulling out effect creates emotional and cognitive backlash. Hence the pupils from mismanaged families become victims of their own upbringing. These factors seem to be due to parents who show lackadaisical attitude on their children's education. In totality administrators and teachers find it difficult to overcome the challenges brought due to the environment in the house and the negative attitude of parents. From anecdotal reports parents who do not give full support to their children's education are mostly underachievers and today earn meagre income to support their families and children. While the Parent Teacher Association (PTA) in all schools function properly, the meetings become a centre of a blaming game. It is from observations by the researchers that parents seem to put the blame on teachers. They accuse them of not teaching well if their children are not performing well in school. On the other hand, from anecdotal information, teachers seem to blame the parents as they do not support the school in implementing programmes to help the underachievers. Some of the counter accusations are not taking initiatives to support the pupils in the houses and at times not allowing the pupils to go to school. It was also found that the children were under stress as their parents scold them for not performing well in their studies. Parents lack knowledge on how to handle these children. This indicates that family (Berns, 2007) is important. It acts as functional interactive unit and it has impact on psychosocial of their children.

The parents think the main reason for the failure rate is due to teachers incompetency. This information was gathered through non formal interaction by the researchers. According to Nek et al. (2007) parents' choice of schools was related to geographical, academic, types of schools, teachers disposition, facilities, and the school culture. Even if these are the factors, there is a contention that all responsibilities are borne by the teachers. According to anecdotal notes remedial classes are difficult to teach because there is no commitment from parents. Suresh (1994) stated that parents' interest was low. Pupils did not even have pens nor pencils. They did not even have preschools. Indian pupils refuse to speak in Malay. Hence the process of teaching and learning was difficult. Pupils were from different dialects and broken families. Family environment contributed to this situation.

\section{Methodology}

A quantitative survey approach (Noraini, 2013, Rozmi, 2013; Adams \& Lawrence, 2015) was applied to conduct this research. A reliable and validated (Cronbach \& Meehl, 1955; Rozmi, 2013) questionnaire (Adam \& Lawrence, 2015) instrument was constructed using the guidance from three survey instruments (Muniandy, 2011). The respondents needed to answer the questionnaire using the 5 item Likert Scale. The questionnaire had 4 sections : Section $A$ understanding about special remedial programme with seven items, Section B parents 
Vol. 7, No. 4, 2018, E-ISSN: 2226-6348 @ 2018 HRMARS

involvement in their children's academic with sub-part A, provision of place to study, five items; sub-part $B$, interaction with their children, five items; sub-part $C$, support for their children, five items; Section $C$, involvement in school with five items. The fourth section, $D$, was on respondents demographic data. The last part being the demographic data is as explained by Jackson, 2011. The initial questionnaire was given to a special needs expert in a teachers' institute to verify the items for construct validity. There were some minor changes. In the end, Section A had ten items, Section B, sub-part A had five items, sub-part B had 11 items, sub-part C had five parts, Section C had eight items. The instrument was tested for construct and content validity. The Cronbach Alpha reading was 0.944 for 50 items.

A pilot study was administered on 20 parents from two special remedial programmes from another district and a mainstream school from the same district. The researchers distributed the questionnaire personally to each parent with explanation on how to answer the questions. Since they were not proficient in the Malay language, the researchers interpreted and explained the items in Tamil, with the meaning of the items intact.

\section{Respondents}

The respondents for this research were 35 parents whose children were in special remedial classes in two Tamil schools in South East Penang. The criteria for using this number of respondents is discussed in Rozmi, 2013. The purposive (Noraini, 2013; Krejcie \& Morgan, 1970; ) sampling for this research was the total number of pupils in the two schools who were attending special remedial classes.

\section{Literature Review}

\section{Tamil schools in Malaysia}

Currently there are 524 Tamil schools in Malaysia and six more in progress. In 2016, the total enrolment for Tamil schools was 13600. Today it has increased to almost 800000 . Quite a number of these schools have low enrolment, 150 and below. Zainudin \& Dineshkumar (2011) indicated that low enrolment schools show very low academic achievement compared to other schools. Until March 2016, there were 360 Tamil schools with low enrolment. The low enrolment is due to social mobility of the Indians from estates to the urban and suburban areas. (SEDIC, 2017). A few years back many buildings were a sore eye, but today many schools have new blocks of buildings. Unfortunately not all have been built and there are still many schools with land issues. The achievement point of each school is compared using Ujian Penilaian Sekolah Rendah (UPSR) results. In 2016, the number of pupils who obtained E in Bahasa Melayu was 10\%. (KPM, 2017). Pupils who fail in Bahasa Melayu cannot be promoted to Form One. They have to spend one year in Remove Class to brush up their Bahasa Melayu language. This automatically increases their age when they leave the school system. Hence many parents and teachers try all their best to make sure that pupils do not waste one year in Remove Class. But this can only be materialized if both parents and teachers collaborate and the first years of the pupils are taken care of in terms of all support needed.

In 2016, Bahasa Malaysia Comprehension paper, for Sekolah Jenis Kebangsaan Tamil (SJKT) indicated Subject Average Grade (GPMP) of 2.70, while Chinese medium schools indicated (GPMP) 2.55 dan National type schools (SK) 2.43. This indicated the number of pupils who passed or obtained A was less compared to the other two types of schools. 


\section{Tamil School Special Remedial Pupils}

Remedial classes began in the 70s in national type schools. Special classes had to be opened to allow pupils were unable to be along their peers in academic. Children who were far behind were taken out of class and taught separately. In some cases all slow readers and low achievers were grouped into one class and taught by a teacher. This teacher may or may not be trained to teach remedial classes. Either way, the scenario seems to be almost similar until today. With the implementation of Literacy and Numeracy Screening (LINUS), pupils in these classes are taught basic literacy and numeracy for a period of three to six months. Once they achieve a standardized level, they are readmitted into their own classes. If they still cannot follow the class, they are placed for OUTREACH porgrammes to screen for any inherent disability so that they can be referred to special education programmes. The curricululm caters for three subjects mainly, Bahasa Melayu, Matemathics and English. When these children reach Year Six, they have to sit for public examination, Pentaksiran Berasaskan Sekolah (PBS) Ujian Pencapaian Sekolah Rendah (UPSR) (Surat Pekeliling Lembaga Peperiksaan Bil. 2 Tahun 2015),

In a survey conducted in 2011, 4,200 Indian students "lagging" in their studies, poor in reading, writing and mathematics in Tamil schools. (STAR, online, 10. Nov. 2011). Pupils who are considered for special remedial classes are those who fail the 12 constructs in language acquisition, reading, writing and arithmetic. The pupils are unable to read and write Bahasa Melayu and English. Their communication in these two languages is limited as they use their mother tongue to communicate. They cannot understand the vocabulary that is in their syllabus. Anecdotal cases indicate that even at UPSR level, pupils who excel in science and mathematics, are unable to understand words like 'air telaga', 'asap berkepul-kepul'. If this is the case after six years in Tamil school, what more of pupils who come from low socio economic background and are neglected by parents and special needs children. Chances are they would be unable to pass the screening test at year 1, Year 2 and Year 3.

Being unable to understand and comprehend in BM and English can make these pupils introverts and have low self esteem. Dhanapal (2007) stated that pupils in Tamil schools in estates, in small towns and in the outskirts have low self esteem and reliance. They are less prepared for intellectual activities. Another factor for pupils to be unable to comprehend in another language is probably they have hidden learning difficulties (Madznah, 1994). Teachers and parents are unable to identify correctly the problems in pupils until the age of nine.

In 2002, there were at least 78000 pupils in all types of schools who were attending the classes in 1999 and by the year 2000 there were 86000 pupils. Almost half of them were able to be remediated (Kannamah, 2012). In 2018, there are around two million pupils in special remedial classes, out of which almost $20 \%$ are in Tamil schools.

\section{Ecological and Family Intervention theories and parenting}

Hugo (2012) says parenting is like engraving letters on the bark of a young tree, it grows, enlarging with its integral part. So parents have to be there to engrave physical and emotional needs of the children. Failure of the parents to meet these needs can result in pupils not performing well in their academic work (Theisen, 2009). These pupils would then have to attend remedial or special remedial classes. Parenting in the 60s, 70s was challenging, dropout cases 
INTERNATIONAL JOURNAL OF ACADEMIC RESEARCH IN PROGRESSIVE EDUCATION AND DEVELOPMENT

Vol. 7, No. 4, 2018, E-ISSN: 2226-6348 ๑ 2018 HRMARS

were almost $50 \%$. Yet the individuals were able to speak read and write. Parents in these eras were struggling to make ends meet. But parents gave the best for their children. Education was the answer to all.

In Bronfenbrenner's microsystem theory, the immediate environment for a child is very important. The immediate environment consists of his parents and siblings and relatives. Parents are directly involved in the growth of the pupils. The parents have to support them in various ways to help them in their studies. This microsystem provides for school and parents to collaborate to help the child. The microsystem provides framework that can be used. These marks the place for interpersonal and intrapersonal on the child development. The principle place for the development is home. Events at home and facilities at home can affect the child's development and comprehension of any information. Bronfenbrenner said that high level of parent involvement in schools can lead to high achievers. The circular causality affects the child behavior and family problems can influence pupils' achievement. It provides the support of understanding the pupils. Any child who does not get the support from the parents can become antisocial. This means that the child lacks self-discipline, and would have no self- direction. This can lead to failures in future.

Smith, Perou and Lesesne (2002) in Koyaruck(2016) claimed that quality relationship between parents and their children was one of the most powerful issues in child development. Hence, it is pertinent that parents play a major role in children's academic achievement. Dunst (2008) said that three important domains are interlocked, that is family concerns and priorities, family interest and abilities and supports and resources. Parents who provide the basics and go the extra milestone will be able to see changes in their children. Children's school needs should be given priorities and this would be helpful in the school. The teachers would then be able to conduct activities without any hitches. The same goes for the support and resources. Visual aids can enhance comprehension and understanding. Hence, if parents provide the learning environment in the house with various visual aids, special remedial pupils would be able to grasp, understand and remember what they learn better. Parenting styles and skills perpetually influence their children's development, which includes cognitive, affective and social skills. The kind of parenting determines cognitive-motivational competence and healthy psychosocial development. Children who receive warm, stimulating, unconditional love and help in their studies at home show high performance. (Volling \& Belsky, 1991; 1992) Beginning from preschool , engagement of parents with their children provides a friendly and uncooperative context for the children to learn from their parents the basics in literacy and numeracy. But this is not seen in the Tamil schools. Parents who spend their time talking and interacting rigorously with their children, help the children to reason, inductively and deductively, increase their self-esteem, and intellectual performance. (Zhao, 2017).

Children benefit a lot by if there exists a close relationship and involved relationship with their parents. Parents who keep tab about what is happening in school will understand the importance of special remedial classes for their children. Not only parents being in the micro system give emotional support, they have to create the conducive environment for their children to learn. Parents whose houses are just a boundary of walls, should also try to provide space for their children to learn. Anecdotal records show that parents watch televisions at night. That is their past time. This hinders their children from studying as there is no place for the children to sit quietly and study. They have to share the hall to study. Parent come home from a long day. 
Vol. 7, No. 4, 2018, E-ISSN: 2226-6348 @ 2018 HRMARS

Most estate workers or parents in Tamil schools whose children are in remedial classes do not have fixed income and work long hours. They have no time to guide the parents by creating time tables or read to them. Most parents have finished till form five, but have no interest in providing a good time table for their children to follow. Interaction as said by Vygotsky is important for the growth of children. This helps in cognitive capacity. The parents have time to interact with the children. Children wit special needs can study effectively if they have emotional balance (Kannamah,2010;Paavola, 2017) has stressed the importance of emotional balance in special needs children to study effectively. Brown (1976) in Robiah (1992) parents should be able to accept children's weakness and indirectly leads to achievement in remedial pupils.

\section{Data Analysis}

The data analysis indicated, min value for parent understanding about SPR was 3.77 (Pupils marks=0.66). Overall the percentage of knowledge was above $80 \%$, except the parents have little knowledge on the curriculum and syllabus and how pupils are screened for this programme.

\section{Participation in children's academic}

Three dimensions were analyzed. (A) Creating the environment for learning, i.e. space for learning, time table, reference books, stationery, ICT gadgets, calm and peaceful place (B) Interaction with children and (C) Support for children. The analysis indicated min value for providing learning environment in the house was $3.02(S D=0.68)$. Majority of parents reduce the volume of the radio or television while children study and buy books and stationery for them. Few parents have special space for studying and the majority of them do not have ICT facilities in the house.

As for interaction with child, the min value for interaction with children was 3.69 $(S D=0.74)$. This meant an average of $80 \%$ parents discuss daily activities of their children in school, discuss the children's problems, give opportunities to children to speak their minds, give praises and reinforcements. Only an average of $50 \%$ parents discuss on co-curricular and recreational activities.

As for support for children, analysis indicated min value for Support for child was 2.95 $(S D=0.76)$. The data indicated an average of $50 \%$ parents take interest in children's attendance, and their completion of school homework. An average of $15 \%$ parents send their children for tuition and extra classes.

\section{Relationship between Provide learning environment with pupils marks}

A spread and linear relationship between provide learning environment with pupils' marks was done. Correlation coefficient Spearman's rho for provide learning environment with pupils marks was $r=0.851$ at Sig $=0.00$. This indicated that there was a strong relationship between both variables in the positive direction (Mohd Yusri, 2010). This indicated provision of learning environment increased pupils' marks. As for interaction with pupils and pupils marks, coefficient, correlation, Spearman's rho $r=0.567$ and Sig value $=0.000$, indicated there was average relationship between the 2 variables in the positive direction. That meant interaction with pupils increased with their marks. Correlation for coefficient Spearman's rho between support for child 
Vol. 7, No. 4, 2018, E-ISSN: 2226-6348 @ 2018 HRMARS

with pupils marks was $r=0.531$ and significance value, $\mathrm{Sig}=0.001$. That indicated there was an average relationship between the 2 variables in the positive direction. That meant support for child increased with pupils marks.

Parents' involvement in school was measured with 8 items. From the 8 items, the min value was $=2.93$ dan $S D=0.60$. The min value and percentage indicated parents' involvement in school has.

An average of $80 \%$ parents have good relationship with school and wanted to be in WhatsApp Remedial programme group. Very few people agreed they attended school activities, and an average of $25 \%$ discussed pupils' achievements with school and in outdoor programmes and activities.

For communication between parents and school in relation to pupils marks, the coefficient, correlation Spearman's rho between parents involvement in school with pupils marks was $r=0.462$, value of Sig $=0.005$. This indicated parents' involvement in school with pupils marks was significant at 0.01 level. That indicated there was an average relationship between the 2 variables, in a positive direction. That meant parents involvement in school raises with pupils' marks.

Coefficient, correlation Spearman's rho between parents involvement in school with pupils marks was $r=0.462$ value of $\mathrm{Sig}=0.005$, indicated parents involvement in school with pupils marks was significant at 0.01 level. That indicated there was an average relationship between the 2 variables, in a positive direction. That meant parents involvement in school raises the pupils marks.

Demography analysis indicated the majority of pupils live with parents, and have a maximum of 5 household members, majority of respondents studied until Form 3 only. Majority of them are labourers and work for 12 hours per day earned less than RM3000 per month.

For the research question on how is parents background related to pupils marks, Coefficient value for correlation Spearman's rho, $r$ for parents education level and marks was 0.029 . Sig value, $p$ was 0.870 , indicated no significant relationship between parents education level and pupils marks. The coefficient value for correlation Spearman's rho for no of working hours to pupils' marks was -0.119 . Sig value, $p=0.495$ indicated no significant relationship between number of working hours with pupils' marks. Correlation Coefficient Pearson for relationship between gross income of family with pupils' achievement was 0.100 . Sig value, $p=0.568$, which indicated no significant relationship between gross income of family with pupils' achievement.

\section{Discussion and Conclusion}

Parents involvement influences pupils marks in an average state, and their social background does not play a $n$ significant role. From the analysis, it can be concluded that many parents support special remedial classes for their slow learning children. A lot of researchers have been conducted on socio economic status (SES), attendance and support (Linn et al., 2011). According to Wilder (2014) there were inconsistencies from previous findings. Most parents are labourers, cleaners and security guards and earn less than RM3000 per month. Correlation analysis indicates there is no status quo with pupils' marks. But Suresh (2014) contended that low SES influences parents' participation in children's academic work. According to him parents with high SES show high commitment. Parents with low SES do not participate in children's 


\section{INTERNATIONAL JOURNAL OF ACADEMIC RESEARCH IN PROGRESSIVE EDUCATION AND}

DEVELOPMENT

Vol. 7, No. 4, 2018, E-ISSN: 2226-6348 @ 2018 HRMARS

wellbeing in school. Stylianides \& Stylianides (2011) and Suresh (2011) argue that high SES group is more dominant in children's education. The findings do not conform to the current findings. Today parents are more concerned. All children should have equitable status. Hence parents do take a lot of effort to monitor their children's education.

Ji \& Koblinsky (2009) also indicated that as the working status is low, they need longer hours to work. This decreases parents' engagement time with children. If both parents are working engagement time with children would be drastically reduced. They would not be able to interact with their children and would not be of much help in their school homework or matters pertaining to school. This is upheld by Green et al. (2007). Here, parents work more than 8 hours, There is no significance on working hours with academic achievement. This indicates that even with the little time they have they do not neglect their children. They make sure they are following the activities in the schools. An average of $50 \%$ parents are able to interact in the house with their children. Probably by the time they come home the children are sleeping and or are too tired to do any work, they just want to relax and sleep.

Parents education background influences their knowledge and skills to help their children. (Green et al. 2007; Suresh (2011). In this research majority of parents have basic education up till Form five and below. With the little education they have do try to be of help for their children.

Some parents in this research have low confidence to help their children in academic because of their handicap in language. This is in contrast to Hornby (2000) who says the ability to support children does not need high level of education.

Some parents are not helping their children because when they were of their age, they too had behavior and learning disabilities. In this research there is no significant relation between parents level of education and children's academic excellence This is again upheld by Hornby \& Lafaele, (2011).

Findings indicated, effective interaction has positive correlation with academic achievement. This is due to lots of praises, motivation, stimulation and reinforcement. Effectiveness is the key to success. Effective talking and stimulation for children brings out the best in them. Children who are happy and are able to listen to their parents show achievements in their studies.

In this research, $60 \%$ parents spent time for recreational purposes. This is quite alarming as compared to what Craig (2006) wrote. He said parents with university education, spend quality time with their children. They listen, play, read and discuss any matters. Hill and Tyson (2009) says parents who provide and have rules for school activities and house and provide conducive environment for learning bring about average impact. In this findings, it shows that parents with low academic standing too have the same sentiments like Craig, 2006 said. Again the importance of education is realized by parents even if their children are attending special remedial classes. In this research, there is strong positive correlation for providing learning environment, average correlation for interaction among parents and children academic achievement. Even with low income and limited space in the house, parents try their best to provide conducive learning. Bronfrenbrenner says the immediate surrounding is important. This is what is indicated by the findings. Parents concern and priority is for their children's education (Dunst, 2008), hence the parents do not compromise on learning environment.

Findings also indicate most parents did have Information and Communication Technology (ICT) gadgets at home. Pupils in the $\mathrm{Z}$ generation are born into technology. The provision of 
Vol. 7, No. 4, 2018, E-ISSN: 2226-6348 @ 2018 HRMARS

technology is of utmost important. Since technology support in teaching and learning is expensive, only some parents have computers and laptops in their house for the remedial children. Again this indicates that parents are concerned about their children.

Parents have good relation with school. On the other hand, they are not keen in cocurricular activities, and actually do not discuss academic and behavior of their children in school. Garry \& Rayleen (2011) says parents without degrees have low self complex and low confidence. Hence probably due to that they find it difficult to cooperate with teacher. Parents might think it is difficult to solve all the problems at home. They might ashamed if they are blamed for their children's performance. This conforms to Kewley (2011) who said parents are always worried if they meet teachers. They would be blamed for all the wrong things.

Today, social media plays a very important aspect of everyone's life. So for teachers and parents groups. Whatsapp group for special remedial class plays an important role. Social media interaction provides avenues for parents teachers to discuss matters on safety, discipline, emergency, accessibility and general wellbeing (Young, 2008). Young also said emails play an effective role in communication. It is cost effective and fast. It does not indicate in this finding. Parents must have knowledge and understanding of what is happening in the school and in the remedial classrooms. Teachers must understand that their children do have the capacity to learn as other children. They are unable to comprehend and understand what is being taught. In this respect parents must find some form of solution to understand what is actually being taught. Knowing what remedial class is insufficient. If they understand the syllabus, they would be able render more help. They must also understand the special roles of teachers in special remedial classes.

Bronfenbrenner, talks about microsystem which affects his performance. So the parents emotional and upbringing influences the children's performance. Parents not only look, give love, discipline their children, teach them social skills, and values, but they also provide physical and emotional energy and effort in promoting their children's academic growth. The potential of the child is influenced by their outlook. Children's movement is to be guided by the management of the parents.

In totality, the research has given a new outlook into special remedial classes in Tamil schools. More research can be conducted on the teachers' roles and look for the reasons on why pupils still fail. The failure at primary level reduces human capital in the future.

\section{References}

Adams, K. A. \& Lawrence, E. K. (2015). Research methods, statistics and applications. USA: Sage Publications.

Berns, R. M. (2007). Child, family, school, community: Socialization and support. USA: Thomson Wadsworth.

Bronfenbrenner, U. (1975). Is early intervention effective? In Friedlander, B. Z., Sterritt, G. M. \& Kirk, G. E. (Eds.), Exceptional infant: Vol. 3. Assessment and intervention, 449-475. New York: Brunner/Mazel 
INTERNATIONAL JOURNAL OF ACADEMIC RESEARCH IN PROGRESSIVE EDUCATION AND DEVELOPMENT

Vol. 7, No. 4, 2018, E-ISSN: 2226-6348 @ 2018 HRMARS

Bronfenbrenner, U. (1979). The ecology of human development: Experiments by nature and design. Cambridge, MA: Harvard University Press.

Craig, L. (2006). Parental Education, Time in Paid Work and Time with Children: An Australian Time-diary Analysis. The British Journal of Sociology, 57(4), 553-575.

Dhanapal, R. (2007). Hubungan Iklim Akademik Murid Sekolah Rendah Jenis Kebangsaan Tamil with Konsep Kendiri, Relians Kendiri dan Kesediaan Intelek. (Disertasi Sarjana Kedoktoran yang belum diterbitkan). Universiti Sains Malaysia, Penang.

Dunst, C. J., Trivaette, C. M. \& Deal, A. (1988). Enabling and empowering families: Principles and guidelines for practice. Cambridge, MA: Brookline Books.

Garry, H. \& Rayleen, L. (2011). Barriers to parental involvement in education: An explanatory model. Educational Review, 63(1), 37-52. DOI: 10.1080/00131911.2010.488049.

Green, C. L., Walker, J. M., Hoover-Dempsey, K. V. \& Sandler, H. M. (2007). Parents' motivations for involvement in children's education: An empirical test of a theoretical model of parental involvement. Journal of Education Psychology, 99(3), 532-544.

Hamer, C. (2012, March). NCT research overview: Parent-child communication is important from birth. Perspective - NCT's Journal on Preparing Parents for Birth and Early Parenthood, 1520.

Hornby, G. \& Lafaele, R. (2011). Barriers to parental involvement in education: An explanatory model. Educational Review, 63(1), 37-52. DOI: 10.1080/00131911.2010.488049.

Hugo, V. (2012). Analysis of Impact from Environmental Factors Evaluated by ICF in Individuals Post-CVA. João Pessoa, PB, Brazil: Universidade Federal da Paraiba (UFPB).V.

Ji, C. S. \& Koblinsky, S. A. (2009). Parent involvement in children's education: An exploratory study of urban, Chinese immigrant families. Urban Education 44(6), 687-709.

Kannamah, M. (2010). Emotional Intelligence among dyslexic children. Unpublished thesis. UIAM.

Kannamah, M. (2012). Remedial and Special Classes In Tamil Schools: A Need Or A Revamp. In: Ewrf Educational Conference, 14-16 Sept 2012, Kuala Lumpur,Malaysia.

Kannamah, M. (2012). Therapeutic model for special remedial teacher.

Kementerian Pendidikan Malaysia (2014, April 2). Data Emis enrolmen murid mengikut jenis sekolah. Pulau Pinang: Jabatan Pendidikan Pulau Pinang. Dipetik dari https://www.moe.gov.my 
INTERNATIONAL JOURNAL OF ACADEMIC RESEARCH IN PROGRESSIVE EDUCATION AND

DEVELOPMENT

Vol. 7, No. 4, 2018, E-ISSN: 2226-6348 @ 2018 HRMARS

Kementerian Pendidikan Malaysia (2012, Oktober 29). Surat Siaran Bahagian Pendidikan Khas: Garis Panduan Pelaksanaan Program Pemulihan Tahun 2012 [KPM.BPKHAS.300-2/2/3 (24)]. Kuala Lumpur: Bahagian Pendidikan Khas.

Kewley, G. (2011). Attention deficit hyperactivity disorder: What can teachers do? (3 ${ }^{\text {rd }}$ ed.). New York: Routledge.

Kocayörük, E. (2016). Parental involvement and school achievement. International Journal of Human Behavioural Sciences. Volume: 2, Issue: 2, Year: 2016. Turkey.

Krejcie, R. \& Morgan. D. (1970). Determining sample size for research activities. University of Minnesota, Duluth.

Madznah. (1994). Pengukuhan dalam bacaan untuk kanak-kanak pemulihan. Kuala Lumpur: Perusahaan Sinaran Jaya.

Mohd Yusri Ibrahim. (2010). Analisis Data Penyelidikan Untuk Pendidikan dan Sains Sosial. Malaysia: Bandar IImu

Muniandy, R. (2011). Parental commitments towards primary school children's academic achievement (Unpublished Research Project for Master's Degree). University Science Malaysia, Penang.

Nek, K., Omar, A. K., Mohamad, K. L. \& Mad, I. S. (2007). Faktor yang mempengaruhi ibu bapa dalam pemilihan sekolah anak mereka di negeri Perak (Kertas Projek Sarjana yang belum diterbitkan). UPSI, Malaysia. Sumber dari http://pustaka2.upsi.edu.my/eprints/id/eprint/544

Noraini, I. (2013). Penyelidikan dalam pendidikan. $2^{\text {nd }}$ ed. Malaysia: McGraw-Hill Education.

Paavola, L. E. (2017). The importance of emotional intelligence in early childhood. Laurea University of Applied Sciences.

Robiah, K. H. (1992). Guru khas pemulihan: Fungsi dan masalah satu kajian. Selangor: Dewan Bahasa dan Pustaka.

Rozmi, I. (2013). Metodologi penyelidikan: Teori dan praktis. Malaysia: Penerbit UKM.

STAR. Online. (2011). 4,200 Indian students "lagging" in their studies.

Stylianides, A. J. \& Stylianides, G. J. (2011). A Type of Parental Involvement with an Isomorphic Effect on Urban Children's Mathematics, Reading, Science, and Social Studies Achievement at Kindergarten Entry. Urban Education 46(3), 408-425. 
INTERNATIONAL JOURNAL OF ACADEMIC RESEARCH IN PROGRESSIVE EDUCATION AND DEVELOPMENT

Vol. 7, No. 4, 2018, E-ISSN: 2226-6348 @ 2018 HRMARS

Suresh, K. (2011). A study of the relationship between Indian parents' education level and their involvement in their children's education. Kajian Malaysia, 29(2), 47-65.

Suresh, K. (2014). Pengaruh sosioekonomi ke atas penglibatan ibu bapa India dalam pendidikan anak di rumah: Satu perbandingan antara murid berpencapaian tinggi dan murid berpencapaian rendah. Jurnal Sarjana , 29(2), 56-73.

Theisen. C. (2009) in Grace, et. al (2012). Roles of parents in the academic performance of elementary school children.

Unit Khas Program Pembangunan Sosioekonomi Masyarakat India (2014). Penempatan semula sekolah kurang murid (SEDIC/SCP/SKM/02). Kuala Lumpur: Jabatan Perdana Menteri.

UPSR 2015: Pencapaian meningkat, 38,344 calon dapat semua A (2015, November 17). Astro Awani Online [Putrajaya]. Retrieved from http://www.astroawani.com/beritamalaysia/upsr-2015-pencapaian-meningkat-38-344-calon-dapat-semua-81170

Volling BL, Belsky J. (1991). The contribution of mother-child and father-child relationships to the quality of sibling interaction: A longitudinal study. Child Development. 1992;63:12091222.

Wilder, S. (2014). Effects of parental involvement on academic achievement: a meta-synthesis. Educational review, 66:3,377-397.

Young, P.G. (2008). Promoting positive behaviors: An elementary principal's guide to structuring the learning environment. USA: Corwin Press.

Zainudin, A. B. \& Dineshkumar, H. (2011). Pencapaian akademik di sekolah jenis kebangsaan (Tamil) yang berstatus sekolah kurang murid (SKM) di daerah Kota Tinggi, Johor (Unpublished). Universiti Teknologi Malaysia, Johor. Dipetik dari http://eprints.utm.my/11735/

Zhao, C. (2017). Impact of parental migration on the psychosocial wellbeing of left behind children in two Chinese provinces: individual experiences, family characteristics, and community contexts. Published thesis, University College London. 